\title{
Afforestation of Former Farmland with High-value Hardwoods
}

\author{
by F.W. von Althen
}

\begin{abstract}
For satisfactory growth, most high-value hardwood species demand a deep, fertile, moist but well drained soil. Intensive competition control during the early years after planting is a necessity. Close spacing is recommended, with gradual release of crop trees to promote high-quality stem development. For good hardwood growth on soils of marginal fertility or poor drainage or on sites where intensive management cannot be guaranteed, it is recommended that a mixture of several hardwood species be planted.
\end{abstract}

\section{Résumé}

Pour que la plupart des essences feuillues de grande valeur aient un taux de croissance satisfaisant, elles doivent pousser dans des sols profonds, fertiles, humides mais bien drainés. Il est absolument nécessaire d'exercer un contrôle intensif de la compétition végétale au cours des premières années après la plantation. Il est recommandé de peu les espacer et de dégager ensuite graduellement les arbres du peuplement final afin de favoriser le développement d'une tige de qualité. Pour obtenir une bonne croissance des feuillus poussant dans des sols à fertilité ou à drainage marginal ou dans des stations où les résultats d'un aménagement intensif ne sont pas assurés, il est recommandé de planter un mélange de plusieurs essences feuillues.

\section{Introduction}

Most hardwood species can be planted successfully on former agricultural land. However, because all high-value hardwoods are very exacting in their site requirements and demand intensive tending to produce satisfactory growth, successful plantation establishment is generally more difficult and more expensive than the establishment of coniferous plantations. This paper briefly discusses the effects of site and of silvicultural treatments such as site preparation, postplanting weed control, spacing and species mixtures on the survival, growth and stem development of the hardwood species most commonly planted in Ontario.

\section{Selection of the Planting Site}

The most important factor in establishing a successful plantation is the selection of a suitable planting site (Loshe 1973, Carmean 1975). Most high-value hardwood species are very demanding in their site requirements and will grow well only on deep, fertile, moist but well drained soils (von Althen 1965, Taylor and Jones 1986). However, these soils are also best for agriculture and are therefore seldom available for afforestation in large tracts. What are generally available for planting are small areas on which farm machinery cannot be operated efficiently-areas that are either inaccessible for part of the year or that are unsuitable for farming. At the same time, most large afforestation areas that have been taken out of agricultural production because of infertility or poor drainage generally contain small areas that are capable of growing high-quality hardwood timber. These are the sites on which hardwoods should be planted.

Although many afforestation sites may cover less than one hectare, a few black walnut (Juglans nigra L.) or red oak (Quercus rubra L.) trees of veneer quality or other hardwood species of sawlog quality grown on such a small area may produce a higher return than pulpwood grown on a much

Forestry Canada, Ontario Region, Great Lakes Forestry Centre, Sault Ste. Marie, Ontario P6A 5M7, Canada.

'The identification of commercial products is solely for the information and convenience of the reader, and does not constitute an endorsement by Forestry Canada, Ontario Region. larger area. Hardwoods may also be planted for their aesthetic and wildlife-habitat values. Although correct site evaluation is not as critical for recreational or wildlife-habitat plantations as for the production of high-value timber, off-site planting may result in plantation failure or unacceptably slow growth.

In southern Ontario, good hardwood planting sites usually occur along creeks and streams, on lower slopes and in depressions where topsoil has accumulated, in abandoned orchards or gardens, and in agricultural fields where the top soil is at least $40 \mathrm{~cm}$ thick. Hardwood seedlings will never produce high-quality timber or beautiful shade trees when planted on dry, exposed slopes and ridges, or in areas where the topsoil is shallow and the subsoil consists of heavy, compacted clay.

\section{Site Preparation and Weed Control}

The second most important factor in successful hardwood plantation establishment is the control of broadleaved weeds and grasses. Site preparation is the first step in effective competition control (Bey et al. 1975, von Althen 1978). By themselves, most site preparation treatments have little effect on long-term tree survival and growth, but in combination with post-planting competition control, the method and intensity of site preparation can greatly improve the success of plantation establishment. The method used will depend on the condition of the soil, topography, accessibility, density and composition of the existing cover, and the cost of the various methods under consideration. Under no circumstances, however, should the success of a plantation be jeopardized by skimping on site preparation and weed control.

Where feasible, plowing and disking of the entire area to be planted is an excellent method of site preparation because it destroys all weeds, including deep-rooted perennial species, and loosens the soil, thereby improving aeration and water infiltration. It also stimulates microbial activity and incorporates plant material into the soil, and in this way improves the soil's organic content and fertility.

Where mechanical site preparation of the entire plantation area is not feasible or desirable (e.g., because the soil is too stony or subject to erosion, or the planting site is partially treed), strips at least $1.5 \mathrm{~m}$ wide should be sprayed in late August with glyphosate (trade names Roundup ${ }^{\circledR}$, Vision $\left.{ }^{\circledR}\right)^{1}$, 
followed by plowing and disking one or two weeks after spraying. Where mechanical site preparation is not possible or desirable, the established vegetation may be eliminated by spraying glyphosate in late August before spring planting. However, this method is not recommended on clay loam or clay soils because reopening of the planting slit caused by soil drying and shrinkage can result in severe root damage to the planted trees.

Individual trees may be planted on weed-free spots prepared by an application of glyphosate in autumn before spring planting. The prepared spot should be at least $1.5 \mathrm{~m}$ in diameter. The larger the spot the better, because large spots promote seedling growth and reduce the danger of stem girdling by mice.

Weed control during the first few years after planting, until the canopy has closed and the trees are able to provide competition control by shading, is essential for successful hardwood afforestation (von Althen 1987). The most efficient method of control is herbicide application over the entire area, the prepared strips or the planting spots. However, many hardwood species are highly susceptible to damage with the herbicide dosages necessary for effective control. To provide the best possible weed control without causing seedling damage, it is important to apply the herbicides only at the recommended dosages and to measure all dosages carefully.

Although many herbicides have been developed and tested, few are registered for forestry use; the most useful herbicide for post-planting weed control in hardwood plantations is simazine (trade names Princep ${ }^{\circledR}$, Simadex $^{\circledR}$ ). Simazine is a selective pregermination herbicide that controls many broadleaved weeds and grasses. It may therefore be applied in plantations without shielding the trees. It is most active in the uppermost $5 \mathrm{~cm}$ of the soil and kills by disrupting photosynthesis of newly germinated plants. It is less effective on deep-rooted weeds or grasses and is ineffective on soils with high organic-matter content (Behrens 1962, Ticknov 1968).

Where chemical weed control is not possible or desirable, competition can be controlled by manual or mechanical methods. Hoeing around trees can be effective but this method is not recommended because it is generally ineffective in maintaining adequate control and often injures tree stems and roots.

Excellent weed control can be attained by disking or rototilling between the rows of trees and spraying glyphosate on the unwanted vegetation within rows. Disking or rototilling once per month from May to September will keep the area between the rows relatively weed free. Glyphosate should be sprayed on the vegetation within the rows at the end of May and during the middle of July. More frequent spraying will be beneficial.

Weed competition may also be reduced by mulching around the trees. Although organic mulches such as bark, sawdust, peatmoss, hay and straw have generally failed to provide prolonged periods of weed control, mulching with plastic film has been more successful (Waggoner et al. 1960, Bowersox and Ward 1970). However, this method is rather expensive.

Mowing between trees has proven ineffective in improving tree growth and may even be harmful because it may stimulate root growth of the weed species and may thereby intensify competition for soil nutrients and moisture. Mowing may be useful to prevent weed species from producing seed and in reducing cover for rodents, but it is ineffective as a substitute for mechanical or chemical weed control (von Althen 1984, 1989).

A promising new weed control method, especially on land that is subject to erosion, is the replacement of the natural weed cover with legumes. Although clean cultivation has generally resulted in the highest survival and height growth of planted black walnut, seeded herbaceous legumes such as hairy vetch (Vicia villosa Roth), common lespedeza (Lespedeza officinalis [L.] Lam.) and sericea lespedeza (Lespedeza cuneata Dumont Mixim.) have significantly improved the growth of black walnut over that in plots with a natural weed cover (Roth and Mitchell 1982, van Sambeek and Rietveld 1982, van Sambeek et al. 1986).

Competition control is essential during the early years after planting, but drastic reduction of the weed cover can also revitalize the growth of trees in stagnating older plantations. Elimination of $90 \%$ of the herbaceous competition increased 4-year diameter and height growth of 8-year-old planted black walnut by 153 and $222 \%$, respectively (von Althen 1985). Competition for $\mathrm{N}$ from broadleaf weeds and grasses was identified as the major cause of growth stagnation in the study plantation.

\section{Spacing}

Initial spacing is an important factor in hardwood plantation establishment because it affects not only the rate of growth and quality of wood produced, but also the cost of establishment, frequency of weed control treatments and thinnings, utilization of the site, land conservation and erosion. Hardwoods are generally more affected by initial spacing than are conifers because many hardwood species lack the drive to upward growth unless they are forced upward by close spacing (Wardle 1967). Most of the successful hardwood plantations established in Ontario before 1950 were planted at spacings of $1.2 \times 1.2 \mathrm{~m}$. Recently, the trend has been towards wider spacings to extend the available planting stock, increase diameter growth, and delay the time of first thinning. However, there are dangers in this approach. Although the diameter growth of trees generally increases with increased growing space, this is true only in closely spaced plantations in which lack of growing space is a limiting factor.

At present, a spacing of $3 \mathrm{~m}$ between rows and $1.5 \mathrm{~m}$ within rows is recommended for intensively managed hardwood plantations. This allows a medium-sized farm tractor to pass between the rows to apply weed control. This spacing also promotes canopy closure approximately 6 to 8 years after planting and thereby reduces the number of weed control treatments required. The disadvantage of this spacing is that thinnings are required, starting approximately 10 to 15 years after planting.

For extensively managed plantations, a 3- × 3-m spacing, which will delay the time of first thinning until age 20 , is recommended. However, weed control treatments may have to be extended because canopy closure may not occur until 12 to 15 years after planting. Pruning will also be required to remove large branches. It is therefore doubtful whether wide spacing will be economically advantageous. 


\section{Species Mixtures}

Hardwood species may be planted either in pure plantations or mixed with other hardwoods or conifers; each procedure has advantages and disadvantages. In natural stands, trees of most North American hardwood species grow in association with those of other species, and plantations of mixed species approximate this natural state. Species mixture may also produce the highest yield since a mixture of different species generally utilizes a planting site more fully than do trees of a single species. The greatest advantage of mixed plantations is that they avoid the problems of monocultures, which are more susceptible to devasting insect or disease attacks. Other advantages are higher values for wildlife habitat and broader aesthetic appeal.

The principal advantage of pure plantations is that, per unit area, they yield the largest number of trees of the desired species. This ensures that sufficient trees are available for the selection of the best crop trees in a fully stocked stand at rotation age. In plantations of black walnut or other valuable species, pure plantations may therefore produce the highest stumpage value. Another advantage of pure plantations is that they permit freedom of choice in the methods of site preparation, planting and weed control used for establishing and managing the species planted.

On intensively managed, highly productive sites, it is generally most economical to plant only the most valuable species. Such plantations may best be compared to fruit orchards. Where intensive management cannot be guaranteed, as on less productive sites and for purposes other than high-quality timber production, a mixture of several hardwood species is recommended. However, all species selected must have compatible growth rates and must be suited to the site. For amenity or erosion-control plantings, any species might be selected so long as its growing requirements match those of the afforestation site.

During the past decade, several studies have shown that interplanting nitrogen-fixing tree or shrub species can greatly increase black walnut growth. Clark and Williams (1979) showed that 10 years after interplanting black walnut with autumn olive (Elaeagnus umbellata Thunb.), the walnut trees were $95 \mathrm{~cm}$ taller than walnut interplanted with black locust (Robinia pseudoacacia L.), the second-best nurse species, and $256 \mathrm{~cm}$ taller than walnut in the control plots. Friedrich and Dawson (1984) found that soil nitrogen concentrations were greatest in the top $30 \mathrm{~cm}$ of the soil in mixed plantations of black walnut and black locust or of black walnut and autumn olive, followed by black walnut and European alder (Alnus glutinosa L. [Gaertn.]), black walnut and lespedeza clover (Lespedeza striata [Thunb.] Hook and Arn.), and control plots. However, Schlesinger and Williams (1984) reported that interplanting black walnut with autumn olive, European alder and black locust increased black walnut tree diameter only at certain locations. Hence, a better understanding of site and nurse-species characteristics is required to obtain the maximum benefit from mixed plantations.

Other advantages of nurse crops are that they provide protection from wind (Schneider et al. 1970), improved natural weed control (Deitschman 1956), and improved stem form of the crop species (Johnston 1979).

Species mixtures may be planted in a variety of arrangements. The simplest and most common configuration is the planting of alternate rows of two species. This facilitates differential weed control and subsequent removal of the less valuable species to provide additional growing space for the preferred species.

Group planting has been employed successfully when a small number of trees of one species is planted in mixture with a large number of trees of another species because the chances of survival and adequate growth are greater for trees planted in groups than for individuals scattered throughout the plantation. Group planting also facilitates weed control, protection from browsing, and thinning to favor the best individuals within a group.

Completely random mixture of many hardwoods may be the most desirable arrangement ecologically because it most closely resembles the arrangement in natural stands. It spreads the risk of plantation failure and generally produces the highest biomass per unit area. However, managing random mixtures for high-quality timber production requires greater expertise than managing mixtures of single-species rows or plantations.

\section{Summary}

Most hardwood species can be planted successfully on former farmland, but establishment of hardwood plantations is generally more difficult and more expensive than that of coniferous plantations. Because most hardwood species have very specific site requirements, selection of a suitable planting site is the most important factor for satisfactory hardwood survival and growth. Control of competing vegetation during the early years after planting is a prerequisite for plantation success. Narrow initial spacing is desirable because it forces growth upward, promotes early canopy closure and reduces the number of weed control treatments required. On the best sites, intensively managed, single-species plantations generally yield the highest returns, whereas on average sites mixtures of several hardwood species are generally more suitable because they afford better site utilization and lower susceptibility to devastation by insects and diseases. In addition, they provide excellent wildlife habitat and have broad aesthetic appeal. Interplanting crop species with nitrogen-fixing tree, shrub or herbaceous legumes offers promise for improving the success of hardwood plantations. On marginal agricultural land of good fertility, hardwood afforestation is an attractive alternative to farming.

\section{References}

Behrens, R. 1962. Soil residues from herbicides. Agric. Chem. 17(34): 78-79.

Bey, C.F., J.E. Krajicek, R.D. Williams and R.E. Phares. 1975. Weed control in hardwood plantations. p. 69-84 in J.S. Wright, $(E d$.) Herbicides in Forestry. For Conf. Proc., West Lafayette, Ind.

Bowersox, T.W. and W.W. Ward. 1970. Black polyethylene mulch - an alternative to mechanical cultivation for establishing hybrid poplar. Tree Planters' Notes 21: 21-24.

Carmean, W. H. 1975. Forest site quality evaluation in the United States. Adv. Agron. 27: 209-269.

Clark, P.M. and R.D. Williams. 1979. Black walnut growth increased when interplanted with nitrogen-fixing shrubs and trees. p. 88-91 in Proc. Indiana Acad. of Sci.

Deitschman, G.H. 1956. Growth of interplanted hardwoods in black locust and shortleaf pine plantations. USDA For. Serv., Central For. Exp. Stn., Note 94, 2 p. 
Friedrich, J.M. and J.O. Dawson. 1984. Soil nitrogen concentrations and Juglans nigra growth in mixed plots with nitrogen-fixing Alnus, Elaeagnus, Lespedeza and Robinia species. Can. J. For. Res. 14: 864-868.

Johnston, E.F. 1979. How to grow black walnuts. Your Forests 12: 22 .

Loshe, C.K. 1973. Selecting the best available soils. p. 33-35 in Proc. symp. black walnut as a crop. USDA For. Serv., North Central For. Exp. Stn., Gen. Tech. Rep. NC-4.

Roth, P.L. and R.J. Mitchell. 1982. Effects of selected cover crops on the growth of black walnut. p. 110-113 in Proc. Symp. Black walnut for the future. USDA For. Serv., North Central For. Exp. Stn., Gen. Tech. Rep. NC-74.

Schlesinger, R.C. and R.D. Williams. 1984. Growth response of black walnut to interplanted trees. For Ecol. Manage. 9: 235-243.

Schneider, G., G. Khattak and J.N. Bright. 1970. Modifying sites for the establishment of black walnut. p. 155-159 in C.T. Youngberg and C.B. Davey (Eds.) Tree Growth and Forest Soils. Oregon State Univ. Press, Corvallis, Oreg.

Taylor, E.P. and R.K. Jones. 1986. Soil interpretation and training for forestry. Ont. Inst. Pedol., Univ. Guelph, Guelph, Ont. $66 \mathrm{p}$.

Ticknov, R.L. 1968. Tolerance of nursery plants to herbicides. Oregon Weed Control Handb. 1968: 141-155.

van Sambeek, J.W., F. Ponder Jr. and W.J. Rietveld. 1986. Legumes increase growth and other foliar nutrient levels of black walnut saplings. For. Ecol. Manage. 17: 159-167.

van Sambeek, J.W. and W.J. Rietveld. 1982. Leguminous cover crops can suppress weeds and accelerate growth of black walnut seedlings in intensively cultured plantations. p. 229-243 in Proc. Fourth Central Hardwood For. Conf., Lexington, Ky.

von Althen, F.W. 1965. Hardwood plantations of southern Ontario. Dep. For. Rur. Dev., Maple, Ont. Rep. 0-X-2. 44 p.

von Althen, F.W. 1978. Preliminary guide to site preparation and weed control in hardwood plantations in southern Ontario. Dep. Environ., Can. For. Serv., Sault Ste. Marie, Ont. Rep. 0-X-288. 22 p.

von Althen, F.W. 1984. Mowing versus mechanical or chemical weed control in sugar maple afforestation. Tree Planters' Notes 35: 28-31.

von Althen, F.W. 1985. Revitalizing a black walnut plantation through weed control and fertilization. For. Chron. 61: 71-74.

von Althen, F.W. 1987. Site preparation and weed control in hardwood afforestation in Ontario. p. 75-80 in Proc. Sixth Central Hardw. For. Conf., Knoxville, Tenn.

von Althen, F.W. 1989. Effects of weed control and irrigation on 7- and 8-year growth of planted black walnut. p. 103-113 in J.E. Phelps and D.R. McCurdy (Eds.) The Continuing Quest for Quality. Proc. 4th Black Walnut Symp. 30 July - 2 August 1989, Carbondale, Illinois. Walnut Council, Indianapolis, Indiana.

Waggoner, P.E., P.M. Miller and H.C. DeRoo. 1960. Plastic mulching, principles and benefits. Connecticut Agric. Exp. Stn. Bull. 634. 43 p.

Wardle, P.A. 1967. Spacing in plantations. Forestry 40: 47-69.

\section{Change of Address}

Date Section

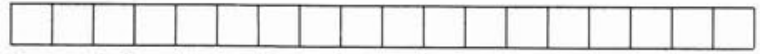

Surname first - no titles
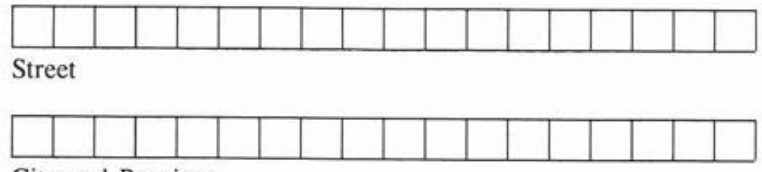

City and Province

Postal Code

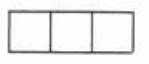

\section{Changement d'adresse}

Date Section

\section{Prénom en avant - pas de titres}

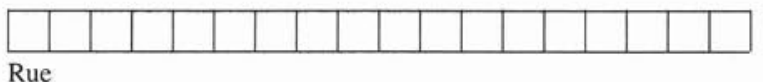

Rue

Ville et Province

Code Postale

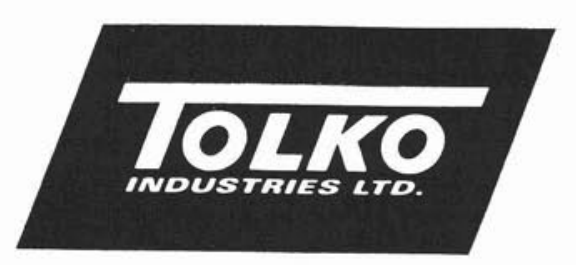

$\overline{\text { A CIF/IFC Corporate Sustaining }}$ Member

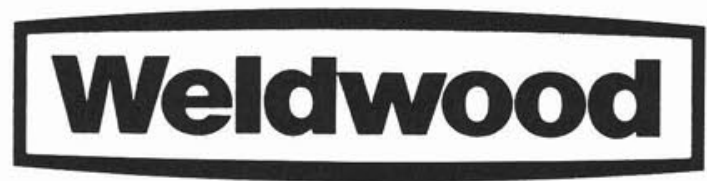

A CIF/IFC Corporate Sustaining Member 